\title{
Diversity of Potato Varieties in Bangladesh
}

\author{
Sharmila Rani Mallick, AKM Quamruzzaman, Md. Altaf Hossain, \\ M. Mizanur Rahman, Md. Azizul Hoque, and Md. Rafiqul Islam
}

\section{ABSTRACT}

A study based on completely randomized design with three replications was carried out at Tuber Crops Research Centre (TCRC), Bangladesh Agricultural Research Institute (BARI), Gazipur with a view to evaluating and classifying agro-morphological traits in 12 potato varieties to enumerating the genetic diversity. Discriminant function analysis (DFA) was done to determine the set of discriminatory functions contributed to separating 12 potato varieties into four distinct clusters. Discriminant function analysis showed that, function 1 explained $78.21 \%$ and function 2 explained $21.79 \%$ of total variance. The first function was more related to leaf area (having coefficient value of 0.661 ) and second function was more related to minituber per plant and plant height (having coefficient value of 0.644 and 0.523 , respectively). Among 4 clusters, cluster II showed the highest distance (29.79) with cluster III followed by the distance between clusters III and IV (24.70) so the varieties in these clusters were genetically diverse. Based on mean value of the six quantitative characters for each of the four clusters and the inter cluster distance the cluster III and IV might be selected for future breeding program as a better parent to get positive heterosis. Cluster III contained six varieties BARI Alu 29, BARI Alu 35, BARI Alu 36, BARI Alu 37, BARI Alu 7 (Diamant), BARI Alu 8 (Cardinal) and which were characterized by lowest plant height and average values for other characters. Cluster IV contained three potato varieties BARI Alu 41, BARI Alu 46 and BARI Alu 53 which was characterized by highest plant height and second highest leaf area.

Keywords: Potato, Agro-morphological traits, Discriminant Function Analysis, Cluster Analysis and yield.
Submitted : April 06, 2021

Published : May 19, 2021

ISSN: $2684-1827$

DOI: $10.24018 /$ ejfood.2021.3.3.281

\section{S. R. Mallick}

Olericulture Division, Horticulture Research Center, Bangladesh Agricultural Research Institute, Bangladesh.

(e-mail: sharmilamallick.2259@gmail.com) AKM Quamruzzaman*

Olericulture Division, Horticulture Research Center, Bangladesh Agricultural Research Institute, Bangladesh.

(e-mail: akmqzs@gmail.com)

M. A. Hossain

Hill Tract Agricultural Research Station, Bangladesh Agriculture Research Institute, Bangladesh.

(e-mail: altafmy@yahoo.com)

M. M. Rahman

Department of Horticulture, Bangabandu Sheikh Mujibur Rahman Agricultural University, Bangladesh.

(e-mail: pallabik1@yahoo.com)

M. A. Hoque

Department of Horticulture, Bangabandu Sheikh Mujibur Rahman Agricultural University, Bangladesh.

(e-mail: a64_sha@yahoo.com)

M. R. Islam

Department of Agronomy, Bangabandu Sheikh Mujibur Rahman Agricultural University, Bangladesh.

(e-mail: rafiarib@yahoo.com)

*Corresponding Author

\section{INTRODUCTION}

Potato (Solanum tuberosum L.) is an autotetraploid $(2 \mathrm{n}=$ $4 \mathrm{x}=48$ ), vegetatively propagated, short-day and a $C_{3}$ plant grown in temperate, subtropical and tropical regions [1]. It is one of the most important vegetable crops, which ranked fourth after rice, wheat and maize in the world [2]. After rice potato is the second most important crop in Bangladesh [3]. It is consumed as vegetable in Bangladesh contributing alone as much as $54 \%$ of the total annual vegetable production of this country. The total potato production in Bangladesh is 109.494 lakh metric tons, total area is 4,69,245 hectare and yield is about 23.3 metric tons per hectare and ranking first among the vegetables in terms of area and production in Bangladesh [4]. In our country about 91 potato varieties are available. The most popular potato varieties are: Diamant, Cardinal, Asterix, Courage, Granola and Lady Rosetta [5].
Maintaining the potato varieties with agronomically important traits, higher yield and good keeping quality is one of the challenges for potato breeders because potato has a tendency to reduce its yield by virus infestation [6]. Minitubers are small seed potato tubers produced after acclimatization from plants propagated in vitro and planted at high density in the glasshouse or net house in seed bed or containers using different substrate mixtures. Minitubers are virus free and principally used for the production of pre-basic or basic seed by direct field planting [7]. Minitubers are generally smaller in size $(5-25 \mathrm{~mm})$ than the traditional seed tubers but larger than micro-tuber produced under aseptic conditions on artificial media [8].

Potato tubers naturally tend to accumulate and transmit viral, bacterial, and fungal diseases to the next generations, and which reduces the yield potentially of potato varieties after few years of cultivation. Hence for sustaining the yield 
potentially, genetic diversity helps identify appropriate parents. Genetic diversity in a population is a prerequisite for an effective plant-breeding program. Genetic divergence is a useful tool for an efficient choice of parents for hybridization to develop high yield potential cultivars. Evaluation of genetic divergence is important to know the source of genes for a particular trait within the available germplasm [9].

Multivariate analysis by means of Mahalanobis $\mathrm{D}^{2}$ statistics is a useful tool in quantifying the degree of genotypic divergence among biological populations and to assess the relative contribution of different components to the total divergence both at inter and intra-cluster levels [10][14]. Many researchers have adopted this $\mathrm{D}^{2}$ technique for measuring divergence among the genotypes [15]-[17]. The $\mathrm{D}^{2}$ statistics can help in selecting desirable parents for achieving desired goal by the breeder. The purpose of this study was identifying the effective traits on yield of potato minituber and classifying the varieties for future potato improvement program.

\section{MATERIALS AND METHODOLOGY}

\section{A. Experimental Site}

The experiment was conducted at the Tuber Crops Research Centre (TCRC), Bangladesh Agricultural Research Institute (BARI), Gazipur, Bangladesh during 2013-14. The soil of the experimental field was having silty clay soil of Madhupur Tract in Agro-ecological Zone 28 (AEZ 28). The soil contains $1.28 \%$ organic matter and $\mathrm{p}^{\mathrm{H}}$ 6.00. The total $\mathrm{N}$, available $\mathrm{P}, \mathrm{S}, \mathrm{B}, \mathrm{Zn}$ and exchangeable $\mathrm{Ca}, \mathrm{Mg}$ and $\mathrm{K}$ were $0.07 \%, 28 \mathrm{ppm}, 10 \mathrm{ppm}, 0,20 \mathrm{ppm}, 0.70 \mathrm{ppm}$ and $6.00 \mathrm{meq} / 100 \mathrm{~g}$ soil, $2.00 \mathrm{meq} / 100 \mathrm{~g}$ soil and $0.11 \mathrm{meq} / 100 \mathrm{~g}$ soil, respectively. The experimental zone was situated in a sub-tropical climate zone and Table I represented the meteorological conditions of the experimental site during the study period and it was noted from the meteorological station of Bangladesh Agricultural Research Institute (BARI), Joydebpur, Gazipur.

TABLE I: METEOROLOGICAL CONDITIONS OF THE EXPERIMENTAL SITE DURING OCTOBER 2013 TO APRIL 2014

\begin{tabular}{cccccc}
\hline \multirow{2}{*}{ Month } & \multicolumn{2}{c}{ Air Temperature $\left({ }^{\circ} \mathrm{C}\right)$} & \multicolumn{2}{c}{ Humidity $(\%)$} & Rainfall \\
\cline { 2 - 5 } & Max. (Average) & Min. (Average) & Max. (Average) & Min. (Average) & $(\mathrm{mm})$ \\
\hline October & 31.5 & 23.23 & 88.74 & 76.29 & 179.00 \\
November & 29.87 & 16.38 & 88.30 & 68.73 & 0.00 \\
December & 24.28 & 13.73 & 88.83 & 69.96 & 3.00 \\
January & 24.29 & 12.06 & 87.35 & 64.51 & 0.00 \\
February & 26.96 & 13.65 & 84.57 & 53.64 & 38.00 \\
March & 31.97 & 18.83 & 81.64 & 42.03 & 4.00 \\
April & 36.25 & 22.79 & 89.16 & 47.56 & 43.00 \\
\hline
\end{tabular}

Source: Meteorological Station, BARI, Joydebpur, Gazipur, Bangladesh.

\section{B. Plant Materials, Experimental Design and Layout}

The In vitro plantlet cuttings of 12 potato varieties named BARI Alu 25, BARI Alu 28, BARI Alu 29, BARI Alu 35, BARI Alu 36, BARI Alu 37, BARI Alu 40, BARI Alu 41, BARI Alu 46, BARI Alu 53, BARI Alu 7 (Diamant) and BARI Alu 8 (Cardinal) were used in the experiment as treatment (Table I). The experiment was laid out in Completely Randomized Design (CRD) with three replications. The entire experimental field was divided into 36 unit plots for 12 treatments and one plot received 100 individuals of each variety. The in vitro plantlets were developed by following a plantlet development protocol [18]. The in vitro plantlets were collected from the Tissue Culture Laboratory, Tuber Crops Research Center, Bangladesh Agricultural Research Institute (BARI), Joydebpur, Gazipur. Then for hardening, the plantlets were transferred to hardening containers and kept in the shady condition in net house for 2 weeks. Transferred plantlets were irrigated with small hand sprayer for initial one week and there after irrigated judiciously with the help of watering can taking care to avoid over or under irrigation. Urea solution @ $0.5 \%$ was applied to the plantlets with watering can. The plantlets were placed on $1^{\text {st }}$ November 2013 for production of minituber.

TABLE II: VARIETIES EMPLOYED AND THEIR CHARACTERISTICS

\begin{tabular}{cccccc}
\hline Varieties & Common Name & Origin & $\begin{array}{c}\text { Year of } \\
\text { Release }\end{array}$ & Yield (t/ha) & Special Characters \\
\hline BARI Alu 25 & Asterix & Netherland & 2005 & $25-30$ & Suitable for processing \\
BARI Alu 28 & Lady Rosetta & Netherland & 2008 & $25-30$ & Suitable for processing \\
BARI Alu 29 & Courage & Netherland & 2008 & $20-26$ & Suitable for processing \\
BARI Alu 35 & - & Bangladesh & 2012 & $30-45$ & Suitable for processing and consumption \\
BARI Alu 36 & - & Bangladesh & 2012 & $30-40$ & Suitable for processing and consumption \\
BARI Alu 37 & - & Bangladesh & 2012 & $30-40$ & Suitable for processing and consumption \\
BARI Alu 40 & - & Bangladesh & 2012 & $35-55$ & Suitable for processing and consumption \\
BARI Alu 41 & - & Bangladesh & 2012 & $38-44$ & Suitable for processing and consumption \\
BARI Alu 46 & - & Peru & 2013 & $35-40$ & Resistant to Late Blight disease \\
BARI Alu 53 & - & Chile & 2014 & $35-40$ & Resistant to Late Blight disease \\
BARI Alu 7 & Diamant & Netherland & 1993 & $25-35$ & Resistant to Blight and Viral diseases \\
(Diamant) & & & & $25-35$ & Resistant to Blight and Viral diseases \\
BARI Alu 8 & Cardinal & Netherland & 1993 & & \\
(Cardinal) & & & &
\end{tabular}

Source: [19].

\section{Land Preparation and Fertilization}

The treatments were assigned randomly to unit plots of the field. The size of unit plot was $1 \times 1 \mathrm{~m}$. The field was prepared by mechanical ploughing followed by laddering and levelling. Full doses of cow dung $\left(10 \mathrm{t} \mathrm{ha}^{-1}\right)$, TSP $\left(220 \mathrm{~kg} \mathrm{ha}^{-1}\right)$, MP $\left(270 \mathrm{~kg} \mathrm{ha}^{-1}\right)$, Gypsum $\left(120 \mathrm{~kg} \mathrm{ha}^{-1}\right)$, Boric acid $\left(6 \mathrm{~kg} \mathrm{ha}^{-1}\right)$ and half doses of Urea $\left(175 \mathrm{~kg} \mathrm{ha}^{-1}\right)$ were applied at the final land preparation. The rest half doses of 
Urea $\left(175 \mathrm{~kg} \mathrm{ha}^{-1}\right)$ were applied at top dressings as 30 DAP followed by earthing up and light irrigation [18]. The plantlets were transferred from the hardening container to the bed. After establishment of the plantlets, ridges were made up by earthing up of side soils. The spacing was $10 \times 10 \mathrm{~cm}$. Intercultural operations were following [20]. The minitubers were harvested at proper maturity after around 90 days of planting.

\section{Data Collection}

Data on different growth and yield contributing characters were recorded on the following parameters from the sample plants of each plot during the course of experiment. The plants in the outer row were excluded during random selection. Ten plants were randomly selected from each plot to record data on mortality $(\%)$, plant height $(\mathrm{cm})$, leaf area $\left(\mathrm{cm}^{2}\right)$, minitubers per plant, weight of minitubers per plant (g), minituber yield per $\mathrm{m}^{2}$, grade of minitubers (by \% No.) and minituber grade by weight $(\%)$.

\section{E. Statistical Analysis}

Descriptive analysis including range, mean and Coefficient of variation was employed to estimate and describe the performance of the genotypes in terms of each character. Non-hierarchical K-mean cluster and Discriminant Function Analysis (DFA) was performed to classify the genotypes into a number of groups. The cluster analysis indicates the grouping of a large number of genotypes into several clusters having similar characteristics on the basis of variables considered in the analysis. Discriminant Function Analysis (DFA) was employed for conformity of the results on grouping the genotypes. DFA has indicated whether a particular set of variables is useful in separating in previously delineated groups. In addition, the precession level of clustering can also be assessed through DFA. The discriminatory functions play the vital role in identifying the set of variables contributed more to clustering a large number of genotypes into homogeneous groups. Through stepwise procedures of DFA, chi-square test, structure matrix of variables, test of equality of group means were done.

\section{DISCUSSION}

\section{A. Clustering of Potato Varieties through Multivariate Analysis}

To make statistically homogenous groups K-mean nonhierarchical cluster analysis was done using six quantitative plant traits for clustering 12 potato varieties. For this two dendrograms were prepared on the basis of hierarchical clustering procedure (Fig. 1) and cluster analysis (Fig. 2). Thus, obtained tree-plot was cut at the rescaled distance of 5 that produced four distinct clusters of genotypes showing much related plant characters of interest and served our purpose better. A list of four clusters of 12 potato varieties with accession is given in Table III.

The grouping of different potato varieties according to clusters for the quantitative traits is presented in Table II. Cluster I comprised of one variety i.e., BARI Alu 40, which represented $8.3 \%$ of the total plant materials. The cluster II contained two varieties (viz. BARI Alu 25 and BARI Alu 28) and accounts for $18.7 \%$ of the population. Cluster III includes six varieties viz. BARI Alu 29, BARI Alu 35, BARI Alu 36, BARI Alu 37, BARI Alu 7 (Diamant), BARI Alu 8 (Cardinal) and represents $50.0 \%$ of the total varieties. The cluster IV comprised of three potato varieties i.e., BARI Alu 41, BARI Alu 46, BARI Alu 53 and contributed $25.0 \%$ of the total.

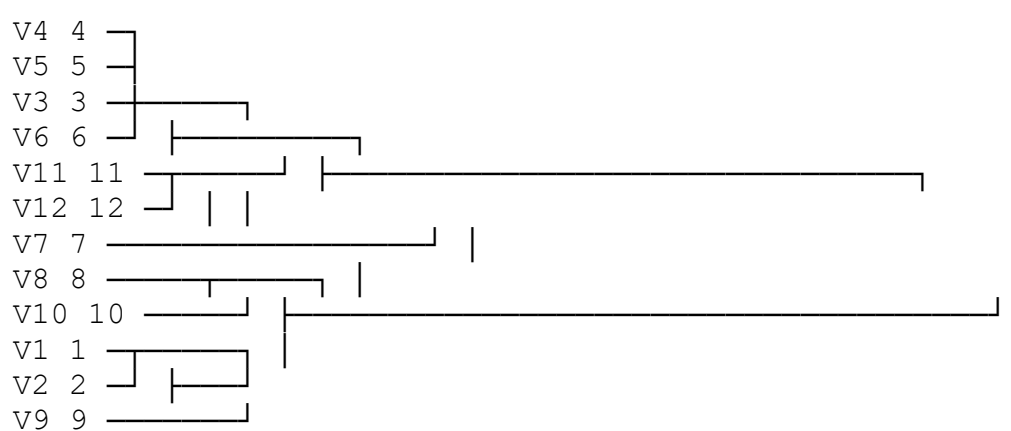

Fig. 1. Dendrogram of six potato varieties derived from average linkage cluster analysis.

TABLE III: GROUPING OF POTATO VARIETIES BASED ON FOUR CLUSTERS FOR SIX TRAITS

\begin{tabular}{cccc}
\hline Cluster & Frequency $(f)$ & Percentage $(\%)$ & Cluster membership \\
\hline I & 1 & 8.3 & BARI Alu 40 \\
II & 2 & 18.7 & BARI Alu 25, BARI Alu 28 \\
III & 6 & 50.0 & BARI Alu 29, BARI Alu 35, BARI Alu 36, BARI Alu 37, BARI Alu 7 (Diamant), \\
IV & 3 & 25.0 & BARI Alu 8 (Cardinal) \\
\hline
\end{tabular}

The distribution pattern of the potato variety under different clusters indicated that the maximum number of varieties (6) was concentrated in cluster III followed by cluster IV (3) and cluster II (2), while cluster I comprised of only one (1) potato varieties. The total number of genotypes for each cluster and mean of each cluster for the six plant characters are presented in Table IV. 
The variety in cluster I is characterized by the highest number of minituber/plant (35.00), weight of minituber/plant $(244.12 \mathrm{~g})$ and tuber yield $\left(12.12 \mathrm{~kg} / \mathrm{m}^{2}\right)$ but has the smallest leaf area $\left(851.67 \mathrm{~cm}^{-2}\right)$, while the Cluster II was characterized by the highest mortality rate (27.00) and leaf area (1225.67 $\mathrm{cm}^{-2}$ ). In contrast, they were characterized by the lowest number of minituber/plant (6.10), lowest weight of minituber/plant (48.58g) and tuber yield $\left(2.43 \mathrm{~kg} / \mathrm{m}^{2}\right)$. The Cluster III presented average values for the analyzed parameters, except plant height $(\mathrm{cm})$, which was the lowest value $64.43 \mathrm{~cm}$ compared to other clusters. Cluster IV was characterized by the highest plant height $(77.93 \mathrm{~cm})$ and second highest leaf area $\left(1139.67 \mathrm{~cm}^{-2}\right)$. They were also having the lowest mortality rate. However, the overall yield performance was medium giving $5.57 \mathrm{~kg} \mathrm{~m}^{-2}$ tuber production. Grouping of large number of genetic resources based on plant traits using multivariate techniques are widely used to identify resources with desirable traits [21]-[23]. It is important to select the lines that are superior in terms of genetic diversity and agronomical properties during the improvement studies [24]-[26].

\section{B. Discriminant Function Analysis}

The contribution of each of two canonical discriminant functions for explaining the variance along with their Eigen values (Latent root) and correlation coefficient of the variables with eigenvectors have been summarized in Table $\mathrm{V}$. Eigenvalues indicates that first two discriminant functions explained 100 percent of total variance. The plants trait leaf area was loaded on function 1 and its contribution was greater (having coefficient value of 0.661 ) in explaining $78.21 \%$ of total variance in plant traits of 12 potato varieties. The coefficients of minituber per plant (0.644) and plant height $(0.523)$ were higher in function 2 indicating that the contribution of these variables to function 2 was higher in explaining $21.79 \%$ of total variance. DFA is particularly useful in defining groups of the varieties as prior classification criteria. Moreover, it provides a graphical output illustrating the existence of groups [27].

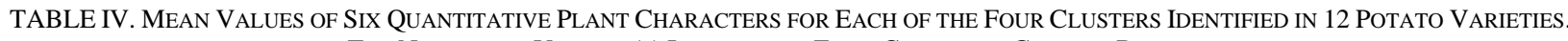

\begin{tabular}{ccccc}
\multicolumn{2}{c}{ THE NUMBER OF VARIETY(S) INCLUDED IN EACH CLUSTER IS GIVEN IN BRACKETS } \\
\hline Variables & Cluster I $(\mathrm{n}=1)$ & Cluster II $(\mathrm{n}=2)$ & Cluster III $(\mathrm{n}=6)$ & Cluster IV $(\mathrm{n}=3)$ \\
\hline Mortality $(\%)$ & 16.29 & 27.00 & 23.82 & 11.78 \\
Plant height $(\mathrm{cm})$ & 67.27 & 70.27 & 64.43 & 77.93 \\
Leaf area $\left(\mathrm{cm}^{-2}\right)$ & 851.67 & 1225.67 & 931.3 & 1139.67 \\
Minituber/plant (no.) & 35.00 & 6.10 & 22.70 & 29.52 \\
Weight of minituber/plant (g) & 244.12 & 48.58 & 110.84 & 115.00 \\
Yield $\left(\mathrm{kg} \mathrm{m}^{-2}\right)$ & 12.21 & 2.43 & 5.54 & 5.75 \\
\hline
\end{tabular}

TABLE V: EIGENVALUES AND EIGENVECTORS OF THE FIRST TwO DISCRIMINANT FUNCTIONS AXIS AS OBSERVED IN 12 POTATO VARIETIES

\begin{tabular}{ccc}
\hline & \multicolumn{2}{c}{ Discriminant function } \\
\cline { 2 - 3 } & $1 \mathrm{st}$ & $2 \mathrm{nd}$ \\
\hline Extracted Eigenvalues & 21.66 & 6.03 \\
Percentage variance & 78.21 & 21.79 \\
& \multicolumn{2}{c}{ Eigenvectors } \\
Plant height $(\mathrm{cm})$ & 0.293 & 0.523 \\
Leaf area $\left(\mathrm{cm}^{-2}\right)$ & 0.661 & 0.030 \\
Minituber/plant (no.) & -0.204 & 0.644 \\
Mortality & -0.242 & -0.315 \\
Weight of minituber/ & -0.012 & 0.044 \\
plant $(\mathrm{g})$ & -0.012 & 0.044 \\
Yield $\left(\mathrm{kgm}^{-2}\right)$ &
\end{tabular}

The graphical presentation of the potato varieties how are they classified into four clusters according to the first two discriminatory functions (Fig. 2). The varieties scattered on the right side of the diagram had higher leaf area and plant height compared to that of the varieties on the left side based on X ordinate. Therefore, function 1 separated cluster I and cluster III very clearly from cluster II and cluster IV based on leaf area and plant height. On the other hand, the varieties scattered on the upper part of the diagram had higher tubers per plants than that of the varieties on the lower part based on Y ordinate. Therefore, function 2 separated clusters I and cluster IV very clearly from cluster II followed by group III.

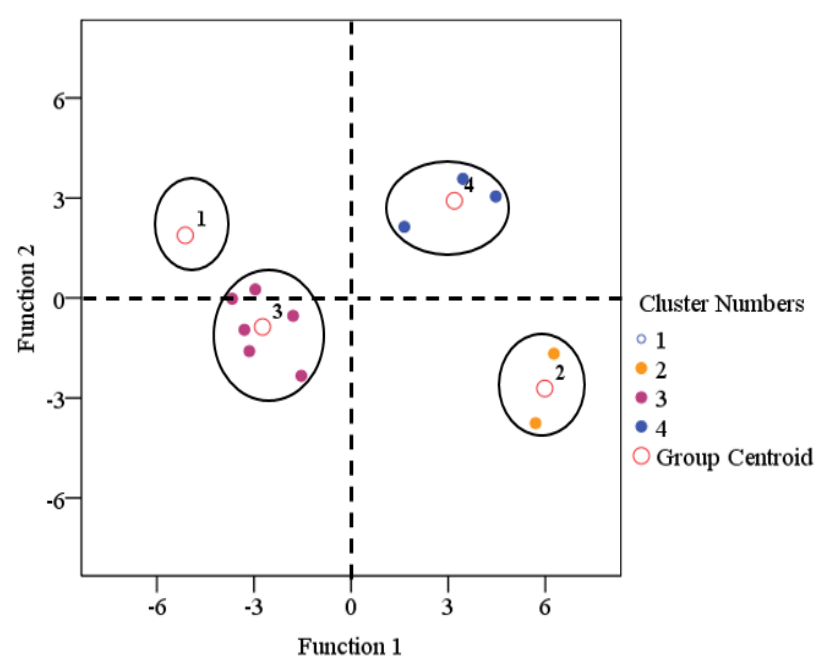

Fig. 2. Graphic illustration of the discriminatory analysis of four groups of potato varieties. The encircled varieties indicate the groups (clusters) obtained through cluster analysis.

\section{Mahalanobis Distance}

The four clusters were statistically different from each other at 0.001 levels according to the Mahalanobis distance $\left(\mathrm{D}^{2}\right)$ among clusters calculated by DFA (Table VI). $\mathrm{D}^{2}$ analysis indicated that the clusters differed significantly from each other. Among 4 clusters, cluster II showed the highest distance (29.79) with cluster III followed by the distance between clusters III and IV (24.70), so the varieties in these clusters were genetically diverse and could be useful for hybridization as a better parent to get positive heterosis [28]. On the other hand, cluster I also showed higher distance (24.08) with cluster II and lowest distance (2.84) was 
observed between clusters I and III. This indicated that the varieties in cluster I and III had a close relationship. All the four clusters showed the minimum intra cluster distance (0.00) which revealed that the varieties within the cluster were very much similar to each other.

TABLE VI: PAIRWISE MAHALANOBIS DistanCE (D2) COMPARISONS BETWEEN FOUR CLUSTERS OF 12 POTATO VARIETIES

\begin{tabular}{ccccc}
\hline Cluster & I & II & III & IV \\
\hline I & 0.00 & & & \\
II & 24.08 & 0.00 & & \\
III & 2.84 & 29.79 & 0.00 & \\
IV & 13.17 & 11.85 & 24.70 & 0.00 \\
\hline
\end{tabular}

\section{CONCLUSION AND RECOMMENDATION}

Considering the mean value of the six quantitative characters for each of the four clusters and the inter cluster distance the cluster III and IV might be selected for future breeding program. Cluster III contained six varieties BARI Alu 29, BARI Alu 35, BARI Alu 36, BARI Alu 37, BARI Alu 7 (Diamant), BARI Alu 8 (Cardinal) and which were characterized by lowest plant height and average values for other characters. Cluster IV contained three potato varieties BARI Alu 41, BARI Alu 46 and BARI Alu 53 which was characterized by highest plant height and second highest leaf area.

\section{ACKNOWLEDGEMENT}

The authors would like to thank the Tuber Crops Research Centre (TCRC), Bangladesh Agricultural Research Institute, Gazipur, Bangladesh for the support and allowing to conduct this research study.

\section{REFERENCES}

[1] Bali S, Patel G, Novy R, Vining K, Brown C, Holm D. 2018. Evaluation of genetic diversity among Russet potato clones and varieties from breeding programs across the United States. PLoS ONE 13(8): e0201415. https://doi.org/10.1371/journal.pone.0201415.

[2] Reddy B.J., et al. 2018. A Review on Potato (Solanum tuberosum L.) and its Genetic Diversity. International Journal of Genetics, ISSN: 0975- 2862 \& E-ISSN: 0975-9158, Volume 10, Issue 2, pp.-360-364. DOI: http://dx.doi.org/10.9735/0975-2862.10.2.360-364.

[3] Rahman, M. H. M. S. Islam and M. Sonom. 2016. Genetic Diversity of Potato (Solanum tuberosum L.). Bangladesh J. Pl. Breed. Genet., 29(1): 39-43, 2016.

[4] AIS, 2020. 2018-19, Orthobosore Nirdharito Lokkhomatra o Orjon. Krishi Diary, Agricultural Information Service. DAE. pp.8-13.

[5] BARI Developed Technology, 2019. Bangladesh Krishi Gobeshona Institute kortik udhvabita Fasaler Jatsomuha 2019. Pp.54-55.

[6] Reddy B.J., et al. 2018. A Review on Potato (Solanum tuberosum L.) and its Genetic Diversity. International Journal of Genetics, ISSN: 0975- 2862 \& E-ISSN: 0975-9158, Volume 10, Issue 2, pp.-360-364. DOI: http://dx.doi.org/10.9735/0975-2862.10.2.360-364.

[7] Ritter, E., B. Angulo, P. Riga, C. Herran, J. Relluso and MJ. San. 2001. Comparison of hydroponic and aeroponic cultivation systems for the production of potato minitubers. Potato Res. 44:127-135.

[8] Struik P.C. 2007. The canon of potato science: 25. Minitubers. Potato Research, 50: 305-308.

[9] Haydar, A., M.B. Ahmed, M.M. Hannan, M.A. Razvy, M.A. Mandal, M. Salahin, R. Karim and M. Hossain, 2007. Analysis of genetic diversity in some potato varieties grown in Bangladesh. Middle-East J. Scientific Res., 2(3-4): 143-145).

[10] Das, P.K. and T.D. Gupta. 1984. Multivariate analysis in black gram. Indian J. Genet. 44 (2): 243-247.
[11] Jatasra, D.S. and R.S. Paroda. 1978. Genetic divergence in wheat under different environmental conditions. Cereal Res. Comm. 6: 307317.

[12] Murty, B.R. and V. Arunachalam. 1966. The nature of genetic divergence in relation to breeding system in crop plants. Indian $\mathrm{J}$. Genet. 26 A. 188-198.

[13] Ram, J. and D.V.S. Panwar.1970. Intra-specific divergence in rice. Indian J. Genet. 30:1-10.

[14] Sachan, K.S. and J.R. Sharma. 1971. Multivariate analysis of genetic divergence in tomato. Indian. J. Genet. 31: 86-93.

[15] Khanna, K.R. and C.H. Misra. 1977. Divergence and heterosis in tomato. SABRAO J. 9(1): 43-50.

[16] Sidhu, A.S. and S. Singh. 1983. Studies on heterosis and divergence in tomato. Pl. Breed Abstracts. 1994. 064-01832.

[17] Masud, M.A.T., M.A.Z. Cowdhury, M.A. Hossain and S.M.M. Hossain.1995. Multivariate analysis in pumpkin (Cucurbita moschata Dueh ex Poir). Bangladesh J. Pl. Breed. Genet. 8(1\&2): 45-50.

[18] Naik, P.S and J.L. Karihaloo. 2007. Micropropagation for production of quality potato seed in Asia-Pacific. Asia Pacific Consortium on Agricultural Biotechnology, New Dehli, India. pp. 39-47.

[19] Kundu, B. C., M. A. Kawochar, M. S. Islam, B. K. Gossami and S. Noor. 2013. Description of high yielding potato varieties in Bangladesh. $1^{\text {st }}$ Edition. Tuber Crops Research Centre, Bangladesh Agricultural Research Institute (BARI), Joydebpur, Gazipur-1701.pp. 7- 41 .

[20] Dey, T.K., Z.H. Prodhan and M.S. Hossain. 2007. Potato late blight and its integrated management (Booklet in Bengali). Breeder Seed Production Centre. Bangladesh Agricultural Research Institute, Debiganj, Panchagarh, Bangladesh.

[21] Karuri, H.W., E.M. Ateka, R. Amata, A.B. Nyende, A.W.T. Muigal, E. Mwasame and S.T. Gichuki, 2010. Evaluating diversity among kenyan sweet potato genotypes using morphological and SSR markers. Intl. J. Agric. Biol. 12(1): 33-38.

[22] Karaca, E., 2004. A study on some phenologic, morphologic agronomic and technologic characters of different originated potato collected surrounding Ordu City. Unpublished Master's Thesis Ondokuz May s University, Turkey.

[23] Racho, B.H.G., E. Augustin, J. Baptista-ta-Silva and J. Viegas, 2001.Isoenzymatic variability in wild potatoes. Pesq. Agropec. Bras, Brasilia. 36: 781-791.

[24] Quamruzzaman, AKM., Ferdouse Islam, M. Nazim Uddin. 2020. Genetic Diversity and Variability of Eggplant in Bangladesh. Journal of Advances in Molecular Biology, 4(2): 24-29. https://dx.doi.org/10.22606/jamb.2020.42002.

[25] Sandhu, S.K. and J. Gopal, 2006.Assessment of genetic diversity in potato germplasm for spring season crop, Crop Improvement. 33: 78 83.

[26] Pandey, S.K., S.V. Singh and P. Manivel, 2005.Genetic variability and causal relationship over seasons in potato, Crop Res. Hisar. 29: 277 281.

[27] Singh, S. P., J. A. Gutierrez, A. Molina, C. Urrea and P. Gepts, 1991. Genetic Diversity in cultivated common bean: marker-based analysis of morphological and agronomic traits. Crop Sci. 31: 23-29.

[28] Mehta, N. B.S. Asati. Genetic relationship of growth and development traits with fruit yield in tomato (Lycopersicon esculentum Mill.). Karnataka Journal of Agriculture Science. 2008; 21(1):92-96.

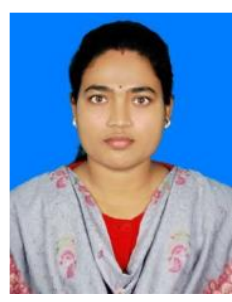

Sharmila Rani Mallick born and brought up in Gazipur, Dhaka, Bangladesh and completed her Master of Science in Horticulture from Bangabandhu Sheikh Mujibur Rahman Agricultural University (BSMRAU) in 2015. Now, she has been associated with a job as a SCIENTIFIC OFFICER at Olericulture Division, BARI, Gazipur, Bangladesh. Around five years of professional career she has already received several professional training and established her as a potential researcher by publishing a number of articles in reputed national and international journals.

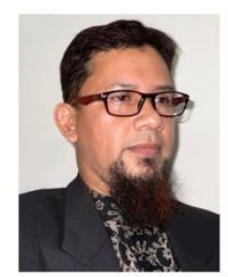

AKM Quamruzzaman born in Dhaka, Bangladesh and got $\mathrm{PhD}$ degree in Horticulture major with Vegetables Breeding from Bangabandhu Sheikh Mujibur Rahman Agricultural University (BSMRAU) in 2011. At present he is currently employed as PRINCIPAL SCIENTIFIC OFFICER at Olericulture Division, BARI, Gazipur, Bangladesh. As a vegetable scientist, he is the principal breeder of Solanaceous and Cucurbitaceous vegetables research. He developed more than 25 vegetables varieties and published more than 60 
European Journal of Agriculture and Food Sciences www.ejfood.org

scientific articles. Dr. Quamruzzaman is an active member of American Society for Horticultural Science (ASHS), Bangladesh Society for Horticultural Science (BSHS), Plant Breeding and Genetics Society of Bangladesh (PBGSB) and also serving as project investigator of FAO, AFACI, WordVeg, NATP, SACP-IFAD.

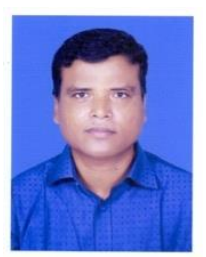

Md. Altaf Hossain is a horticulturist and now working as a PRINCIPAL SCIENTIFIC OFFICER at Hill Tract Agricultural Research Station, Bangladesh Agriculture Research Institute, Raikhali, Rangamati.

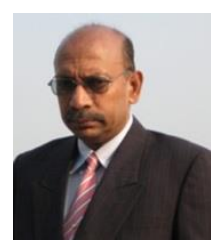

M. Mizanur Rahman, Professor of Department of Horticulture, Bangabandu Sheikh Mujibur Rahman Agricultural University. Salna, Gazipur-1706, Bangladesh.

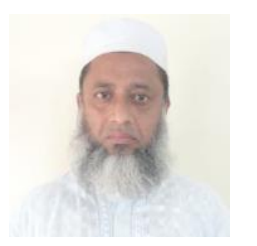

Md. Azizul Hoque, Professor of Department of Horticulture, Bangabandu Sheikh Mujibur Rahman Agricultural University. Salna, Gazipur-1706, Bangladesh.

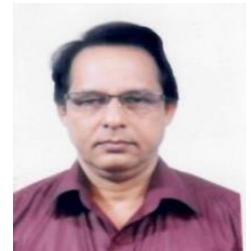

Md. Rafiqul Islam, Professor of Department of Agronomy, Bangabandu Sheikh Mujibur Rahman Agricultural University, Salna, Gazipur-1706. 